\title{
THE Saccharomyces sp. AND Bacillus subtilis BASED PROBIOTICS INFLUENCE ON CHICKEN BROILER PRODUCTIVITY AND CAECUM MICROBIOME COMMUNITY
}

\author{
T.A. EGOROVA' 1 , T.N. LENKOVA ${ }^{1}$, L.A. IL'INA ${ }^{2}$, E.A. YILDIRIM ${ }^{2}$, I.N. NIKONOV ${ }^{2}$, \\ V.A. FILIPPOVA ${ }^{2}$, G.Yu. LAPTEV 2 , N.I. NOVIKOVA ${ }^{2}$, A.A. GROZINA ${ }^{1}$, \\ V.A. MANUKYAN', V.I. FISININ 1 , I.A. EGOROV1
}

\author{
1All-Russian Research and Technological Poultry Institute, Federal Agency of Scientific Organizations, 10, ul. Pti- \\ tsegradskaya, Sergiev Posad, Moscow Province, 141311 Russia, e-mail olga@vnitip.ru; \\ ${ }^{2} J S C$ «Biotrof», Kolpino, St. Petersburg, 192288 Russia, e-mail nikonov@biotrof.ru \\ Acknowledgements: \\ Supported by grant from Russian Science Foundation (project № 14-16-00140 «Modern views on the intestinal \\ microflora of poultry in different diets: molecular genetic approaches») \\ Received September 26, 2016
}

\section{Abstract}

Study of probiotic microorganisms which can produce enzymes and amino acids is important to develop biologicals to prevent disease and increase productivity in poultry. Lactbacillus sp. and Bifidobacterium sp. are widely used as probiotics due to their adhesive ability and antipathogenic activity. Bacillus sp. and yeasts Saccharomyces sp. are less examined but considered perspective as probiotic agents due to antibiotic activity and some other helpful features. Using T-RFLP (Terminal Restriction Fragment Length Polymorphism) and Real-Time PCR we compared number and composition of caecum microbiome in 37-day old Cobb 500 broiler chicken. In group I the chickens were fed with balanced combined fodder. In group II the chickens were fed with the same combined fodder supplemented with a probiotic which contained Saccharomyces sp. living cells, and in group III this probiotic was replaced by a probiotic product Cellobacterin-T. Chickens' caecum microbiome contained various taxa including several unidentified phylotypes in addition to commonly found gut microorganisms. Phylum Firmcutes (mainly cellulolytic and amylolitic Clostridia) and Bacillus sp., Lactobacillus sp., Enterococcus sp. which possess anti-bacterial activity are identified as predominating taxa. In addition, various opportunistic and pathogenic microorganism were found including causative agents of respiratory diseases (Pasteurellaceae, Mycoplasma sp., etc.). Both probiotics resulted in an increase of total caecum microbiome and a decreased of its biodiversity. The most remarkable changes we found in the chickens fed with yeast probiotic. Caecum microbiome community of the broilers from group II showed the lowest Shannon index and Simpson index. Cellobacterin-T had the highest probiotic effect. In the broilers from group III the microbiome Bacillus sp. counts increased 1.38-fold, Lactobacillus sp. number was 1.47 times higher whereas the Campylobacter sp. number was 3.00 times lower and the family Enterobacteriaceae number was 1.44 times lower as compared to the control chicks. Yeast probiotic resulted in positive effect on cellulolytic Clostridia microorganisms but also led to rise of Campylobacter sp., Pasteurella sp. and Mycoplasma sp. counts. Poultry growth rate and productivity were influenced positively by both probiotics. The highest growth rate, weight gain, digestibility coefficient and vitamin $\mathrm{A}, \mathrm{E}, \mathrm{B}_{2}$ and carotinoid accumulation in liver were characteristic of the chickens from group III. Yeast probiotic promoted feed consumption. Chemical composition of pectoral and leg muscles of the chicks fed with probiotics remained unchanged.

Keywords: microflora, caecum, broiler chickens, bacterial community, T-RFLP, real time PCR, probiotic, Cellobacterin-T, yeast, productivity

Nowadays the studies of effect of probiotics based on beneficial microorganism strains, producing enzymes, amino acids and other biologically active substances, on the intestinal microbiome content of poultry, are of fundamental scientific interest $[1,2)]$. It is known that normal intestinal microflora affects the macroorganism immune system formation, contributes to inactivation of some harmful decomposition products, and prevents reproduction of opportunistic bacteria [3, 4]. In poultry, gastrointestinal tract (GIT) caecum, where the intes- 
tine content remains for the longest time, and the basic processes of microbial proteolysis and cellulose and starch cleavage take place, is usually studied [5, 6].

Bacteria of the genus Bacillus are promising subjects for development of probiotics. For example, the species Bacillus subtilis, B. licheniformis, B. coagulans, B. clausii, B. pumilus, and B. cereus have been tested as probiotics for human use [7]. The properties of bacilli differ significantly from those of classic probiotic microorganisms, such as lactobacilli or bifidobacteria; however, they have a number of benefits. First of all, the bacilli are more resistant to GIT conditions because of spore formation [8]. It has been shown that the baccilli are able to colonize the digestive tract of poultry, interacting both with intestine epithelium of the host organism and directly with microorganisms that inhabit GIT. Most bacilli are capable of synthesis of organic acids, bacteriocins, and antibiotic substances, so they may act as antagonists forcing pathogens (salmonellas, proteus, staphylococci, E. coli, and streptococci) out of the intestine [8, 9]. Apart from that, most bacilli strains show significant enzyme activity and contribute to processes of metabolism of various nutritious substrates.

Yeasts Saccharomyces sp. are of interest as a probiotic for poultry because of production of various antibiotic compounds, inhibiting the growth of pathogens [10, 11]. Antibiotic resistance is the key competitive advantage of yeasts. Positive effect of yeasts on intestine mucosa (i.e. increase in villi size and density of goblet cells), and on performance of various monogastric animals and ruminants has been reported $(12,13)$. A positive effect of yeasts is related to both metabolites produced and components of their cell walls [14, 15]. The studies also confirm positive effect of probiotic microorganisms on immunity in poultry [16-18]. For example, ability of two strains, Saccharomyces boulardii and $B$. subtilis, to activate the immunity due to interaction with toll-like receptors (TLR) of poultry cells has been demonstrated recently [18-20].

Despite of the widespread interest in the subject, the mentions microorganisms are relatively new probiotics in poultry farming. The effect of baccilli and yeasts on intestine microbiocoenosis and productivity performance is still not fully understood. The work becomes more complicated due to nearly complete absence of methodological base for studies of facultative anaerobic and strictly anaerobic microorganisms inhabiting the digestive tract of poultry.

According to traditional concepts based on classical microbiology methods, bifidobacteria, lactobacilli, nonspore-forming anaerobes, and bacteroides prevail among the intestine microorganisms [21, 22]. The advances in microbiology of the recent decades allow for analysis of intestine microorganism composition using molecular-genetic methods and determination of microbial diversity without the culturing stage [23-24]. As a result, the presence of significantly larger amount of species was identified, comparing with that previously suggested, which lead to reevaluation of classical concepts. Molecular-genetic methods, such as T-RFLP analysis, ensure detailed characterization of microbial community, identification of taxonomic dominants and minor components, including uncultured microorganisms, the proportion of which in various ecosystems may be as high as $90 \%$ [25]. Real time PCR method ensures determination of quantity of microorganisms within an ecosystem [26]. However, there are only a few examples of molecular genetic studies of intestine microbiome [24-28], and the data on effect of bacilli and yeast probiotic strains on microbiocenosis of intestine content are nearly almost absent.

In this study we first have demonstrated the effect of live Saccharomyces yeast product and cellobacterine-T, a probiotic based on B. subtilis bacteria, on caecum bacterial community, using T-RFLP and real time PCR. By a biodiversity coefficient analysis, the yeast biological was shown to have the most signifi- 
cant effect on the bacterial community. However, probiotic effect on pathogenic microorganisms was higher when using the bacterial product.

This work focused on caecum bacteria characteristics and productivity in broiler chickens, as influenced by dietary probiotics based on Saccharomyces (yeasts) and Bacillus subtilis (bacteria).

Technique. The study was performed in 3 groups of Cobb 500 broiler chickens from 1 to 37 days of age (Zagorskoe EPH VNITIP vivarium, Moscow region). Chickens were fed manually, ad libitum with dry complete feed according to the cross standards. Group I (control) chickens were fed with balanced complete feed (BD). In group II the same feed was enriched with foreign-manufactured probiotic based on live Saccharomyces yeast cells at a dose of $1 \mathrm{~kg} / \mathrm{t}$. Group III broilers were provided with the same BD with addition of cellobacterine-T probiotic (JSC Biotrof) at a dose of $1 \mathrm{~kg} / \mathrm{t}$. The broilers consumed the same pre-starter granulated feed during the first 5 days; later they were fed according to the experimental design.

The broilers were kept in cage AviMax batteries (Big Dutchman Livestock Equipment Co., Ltd, China) in groups with no gender separation, in compliance with all technological norms of the All-Russian Poultry Research and Technology Institute (VNITIP).

The following parameters were estimated: stock preservation, live weight of broilers at the age of 7,21, and 37 days (individual weighing), average daily live weight gain, feed consumption and conversion rate per $1 \mathrm{~kg}$ of live weight, the levels of vitamins and carotenoids in the liver, chemical composition of pectoral and femoral muscles, digestibility and utilization of the feed nutrients based on a physiological balance between their intake and excretion [29].

Bacterial community composition was examined by T-RFLP and real time PCR methods. Caecum content for molecular studies was collected aseptically from slaughtered 37-day old poultry in accordance to requirements [30].

Total DNA was isolated using Genomic DNA Purification Kit (Fermentas, Inc., Lithuania) according to manufacturer's manual. PCR was performed using a Verity DNA amplificator (Life Technologies, Inc., USA) and eubacterial primers, the 63F (CAGGCCTAACACATGCAAGTC) marked on 5' end (fluorophore WellRed D4, Beckman Coulter, USA), and 1492R (TACGGHTACCTTGTTACGACTT). Fluorescence-labelled products of 16S rRNA gene amplification were purified as described [31]. The amplicons (30-50 ng) were digwsted with restriction endonucleases HaeIII, HhaI and MspI following the manufacturer's protocol (Fermentas, Lithuania). Restriction products were analyzed on a CEQ 8000 (Beckman Coulter, USA) according to the attached manual. Phylogenetic status of bacteria was determined using Fragment Sorter software (http://www.oardc.ohiostate.edu/trflpfragsort/in-dex.php). Real time PCR to account for the total number of bacteria was performed on a DT Lite-4 amplifier (OOO NPO DNA Technology, Russia) with the Reagents for qPCR in the presence of intercalating EVA Green stain Kit (JSC Syntol, Russia) and Eub338/Eub518 primers (5'-ACTCCTACGGGAGGCAGCAG-3' and 5'-ATTACCGCGGCTGCTGG-3') by the following protocol: $95^{\circ} \mathrm{C}$ for $3 \mathrm{~min} ; 95^{\circ} \mathrm{C}$ for $13 \mathrm{sec}, 57^{\circ} \mathrm{C}$ for $13 \mathrm{sec}, 72^{\circ} \mathrm{C}$ for $30 \mathrm{sec}$ ( 40 cycles).

MS Excel 2010 dispersion analysis software was applied for quantitative data processing. Shannon and Simpson biodiversity coefficients were calculated using Past software (http://folk.uio.no/ohammer/past/).

Results. It is known that bacteria act as taxonomic dominants in caecum microbial community and, according to traditional concepts, play an important role in provision of nutritional components, vitamins and other vital substances in poultry. The total number of bacteria in poultry caecum in the control group 
amounted to $2.43 \times 10^{8} \pm 8.31 \times 10^{6}$ genome equivalents/g (Table 1). Addition of live microorganism cells to the diet of broilers lead to significant increase in this parameter in both experimental groups -2.88 -fold for dietary cellobacterine-T and 1.77-fold for dietary yeast probiotic.

The caecum bacterial community was taxonomically diverse. We observed maximum biodiversity in chickens of the control group. When dietary probiotics were administrated, this parameter decreased by $12.32 \%(\mathrm{P}<0.05)$ and $21.09 \%$ for groups II and III, respectively, as compared to the control (see Table 1). Taxonomic analysis also revealed a significant proportion of DNA sequences (from $18.92 \pm 0.67$ to $24.19 \pm 1.12 \%$, depending on the experimental group) that could not be identified. The presence of unidentified microorganisms in caecum has been previously observed [32, 33], which is indicative of complete absence of knowledge on their existence.

1. The number and proportion of bacterial taxa in caecum of 37 day-aged Cobb $\mathbf{5 0 0}$ broilers, as influenced by dietary cellobacterine-T probiotic and a yeast-based probiotic ( $X \pm x$, Zagorskoe EPH VNITIP vivarium, Moscow region).

\begin{tabular}{|c|c|c|c|}
\hline Parameter & $\begin{array}{l}\text { Group I } \\
(\text { control, } n=3)\end{array}$ & Group II $(n=3)$ & Group III $(n=3)$ \\
\hline Total number of bacteria, genome eq./g & $2.43 \times 10^{8} \pm 8.31 \times 10^{6}$ & $4.31 \times 10^{8} \pm 3.15 \times 10^{6 * * *}$ & $7.02 \times 10^{8} \pm 1.42 \times 10^{6 * * *}$ \\
\hline Shannon biodiversity index & $4.28 \pm 0.20$ & $4.00 \pm 0.19$ & $4.21 \pm 0.17$ \\
\hline Simpson biodiversity index & $0.98 \pm 0.04$ & $0.96 \pm 0.03$ & $0.98 \pm 0.03$ \\
\hline The number of phylotypes, units & $155 \pm 6.24$ & $128 \pm 5.93^{*}$ & $138 \pm 5.45$ \\
\hline \multicolumn{4}{|l|}{ Taxon frequency, $\%$} \\
\hline phylum Bacteroidetes & $22.00 \pm 1.09$ & $21.18 \pm 0.87$ & $20.69 \pm 1.01$ \\
\hline phylum Firmicutes & $39.09 \pm 1.85$ & $43.05 \pm 1.99$ & $42.85 \pm 2.11$ \\
\hline class Clostridia & $19.49 \pm 0.79$ & $23.90 \pm 1.20^{*}$ & $21.60 \pm 0.88$ \\
\hline family Lachnospiraceae & $2.96 \pm 0.12$ & $2.20 \pm 0.10^{* *}$ & $2.32 \pm 0.10^{* *}$ \\
\hline family Eubacteriaceae & $6.06 \pm 0.28$ & $9.97 \pm 0.38 * * *$ & $8.50 \pm 0.09 * * *$ \\
\hline family Ruminococcaceae & $3.50 \pm 0.16$ & $4.80 \pm 0.21 * *$ & $4.09 \pm 0.13^{*}$ \\
\hline family Clostridiaceae & $6.63 \pm 0.21$ & $6.29 \pm 0.24$ & $5.64 \pm 0.35$ \\
\hline genus Peptococcus & $0.34 \pm 0.02$ & $0.64 \pm 0.03^{* * *}$ & $1.05 \pm 0.04 * * *$ \\
\hline genus Lactobacillus & $3.58 \pm 0.16$ & $4.31 \pm 0.19 *$ & $5.29 \pm 0.22 * * *$ \\
\hline genus Enterococcus & $2.81 \pm 0.11$ & $1.44 \pm 0.06^{* * *}$ & $1.57 \pm 0.08 * * *$ \\
\hline genus Bacillus & $4.55 \pm 0.21$ & $3.84 \pm 0.16^{*}$ & $6.30 \pm 0.28 * *$ \\
\hline genus Staphylococcus & $1.22 \pm 0.05$ & $0.90 \pm 0.04 * *$ & $1.31 \pm 0.06$ \\
\hline order Negativicutes & $7.44 \pm 0.32$ & $8.66 \pm 0.38$ & $6.78 \pm 0.31$ \\
\hline phylum Actinobacteria & $4.81 \pm 0.23$ & $3.96 \pm 0.17 *$ & $4.53 \pm 0.21$ \\
\hline genus Bifidobacterium & $1.55 \pm 0.06$ & $1.07 \pm 0.04 * * *$ & $1.26 \pm 0.12$ \\
\hline other & $3.26 \pm 0.12$ & $2.86 \pm 0.11^{*}$ & $3.27 \pm 0.10$ \\
\hline phylum Proteobacteria & $6.14 \pm 0.28$ & $8.08 \pm 0.39^{*}$ & $7.95 \pm 0.31^{*}$ \\
\hline family Enterobacteriaceae & $2.70 \pm 0.09$ & $2.00 \pm 0.04 * * *$ & $1.87 \pm 0.05^{* * *}$ \\
\hline family Campylobacteriaceae & $0.33 \pm 0.01$ & $0.49 \pm 0.02 * * *$ & $0.11 \pm 0.01 * * *$ \\
\hline family Pseudomonadaceae & $2.52 \pm 0.16$ & $4.86 \pm 0.22 * * *$ & $5.21 \pm 0.19^{* * *}$ \\
\hline family Pasteurellaceae & $0.59 \pm 0.03$ & $0.73 \pm 0.03 *$ & $0.66 \pm 0.06^{* * *}$ \\
\hline phylum Tenericutes (genus Mycoplasma) & $3.02 \pm 0.14$ & $3.84 \pm 0.10 * *$ & $3.06 \pm 0.16$ \\
\hline phylum Fusobacteria & $0.75 \pm 0.12$ & $0.97 \pm 0.15$ & $0.87 \pm 0.14$ \\
\hline unclassified sequences & $24.19 \pm 1.12$ & $18.92 \pm 0.67^{* *}$ & $20.15 \pm 0.98^{*}$ \\
\hline
\end{tabular}

The identified microorganisms included six phyla, mainly phylum Firmicutes, including bacteria of families Bacillaceae, Lactobacillaceae, Lachnospiraceae, Ruminococcaceae, Clostridiaceae, Eubacteriaceae. Microorganisms of phylum Proteobacteria, Bacteroidetes, Actinobacteria, Tenericutes and Fusobacteria were less abundant.

The numbers of detected opportunistic and pathogen microorganisms of genus Staphylococcus and families Campylobacteriaceae и Enterobacteriaceae, normally observed in GIT of poultry, were small. The presence of these microorganisms is usually related to dysbiotic GIT disorders in mammals and poultry. Apart from that, pathogens of families Pasterellaceae and Actinobacteriaceae and phylum Fusobacteria were identified, which were discovered in poultry GIT only due to molecular methods [24, 34]. The presence of bacteria of family Pas- 
terellaceae and genus Mycoplasma in GIT of broiler chickens, which are mostly found in the respiratory tract of poultry and are considered as respiratory pathogens, is of significant interest.

Our findings are generally consistent with the present-day concepts of bacteria quantity and composition in the poultry caecum. The monograph by M.A. Timoshko [22] describes the following bacteria in poultry intestine, found by traditional methods of microbial detection: bacteroides, eubacteria, peptococci, lactic acid bacteria, bifidobacteria, streptococci, enterobacteria, staphylococci, bacilli. Domestic and foreign publications based on next-generation sequencing (NGS) and T-RFLP analysis confirm the presence of numerous microorganisms, including various pathogenic bacteria of genera Campylobacter, Arcobacter, Shigella, Salmonella, Enterobacter.

We have shown that dietary yeast and bacterial probiotics contributed to the change of qualitative and quantitative composition of bacterial microbiota in broilers' caecum.

In the chickens from group III, fed with dietary cellobacterine-T, the Bacillus sp. counts increased 1.38 -fold $(\mathrm{P}<0.01)$ as compared to the control, which was evidently related to successful colonization and reproduction of the introduced baccilli. These results are in line with data that some bacilli species, including $B$. subtilis, are capable of adhesion to intestine mucosa. It allows them to colonize the digestive tract and occupy free ecological niches of intestine microbiome, that resulted in a probiotic effect [9, 35]. In contrast, in the broilers from group II the proportion of bacilli decreased by $18.49 \%(\mathrm{P}<0.05)$.

The number of bacteria from genus Lactobacillus increased by $20.39 \%$ $(\mathrm{P}<0.05)$ and $47.77 \%(\mathrm{P}<0.005)$ in groups II and III, respectively. These microorganisms are known to be capable of competitive exclusion of pathogens due to production of organic acids and bacteriocins. The amount of other microorganisms of genus Enterococcus and family Bifidobacteriaceae, which are similar in properties, decreased by $95.13 \%(\mathrm{P}<0.005)$ and $78.98 \%(\mathrm{P}<0.005)$, and by $44.86(\mathrm{P}<0.005)$ and $23.02 \%$ for groups II and III, respectively.

Dietary probiotics had practically no effect on the phylum Bacteroidetes bacteria with cellulolytic and amylolytic enzymes but directly affected bacteria of phylum Firmicutes with similar properties. Interestingly, the effect of bacterial and yeast products on the said microorganisms was similar. An increase in proportion of families Eubacteriaceae and Ruminococcaceae, genus Peptococcus, and a decrease in Clostridiaceae and Lachnospiraceae counts occurred in both experimental groups, as compared to the control. The total proportion of the listed microorganisms from class Clostridia increased by $22.63 \%(\mathrm{P}<0.05)$ and $10.83 \%$, when using probiotic products in groups II and III, respectively, as compared to the control.

Inclusion of probiotics in the diet had a positive effect on decrease in content of pathogens in caecum. The probiotics decreased the number of opportunistic enterobacteria in groups II and II by $35.00 \%$ and $45.94 \%$ compared to control. Apart from that, cellobacterine-T has reduced 3 -fold $(\mathrm{P}<0.005)$ the count of campylobacteria of family Campylobacteriaceae, pathogenic for both poultry and humans. Administration of yeast product lead to a decrease in proportion of staphylococci by $35.56 \%(\mathrm{P}<0.01)$, with increase in other pathogenic bacteria, i.e. by $48.50 \%(\mathrm{P}<0.005)$ for campylobacteria, by $23.72 \%(\mathrm{P}<0.05)$ for pasteurella, and by $27.15 \%(\mathrm{P}<0.05)$ for mycoplasmas.

The difference in broiler caecum microbiome composition resulted from feeding bacterial and yeast probiotics was apparent from biodiversity indices (see Table 1). Shannon indices were lower in chickens fed with dietary probiotics, which indicates more stable and uniform microbiocoenosis composition. The 
difference between caecum bacterial community of these chickens and microbiome of other groups appeared to be the most significant for yeast probiotic, and was characterized by the smallest Shannon index $(4.00 \pm 0.19)$ and Simpson dominance index $(0.9 \pm 0.03)$, which is indicative of more expressed effect of this product.

In all groups, the viability amounted to $100 \%$, and poultry performance was associated with the changes in the bacterial community (Table 2).

2. Productivity in Cobb 500 broiler chickens, as influenced by dietary cellobacterineT probiotic and a yeast-based probiotic $(X \pm x$, Zagorskoe EPH VNITIP vivarium, Moscow region)

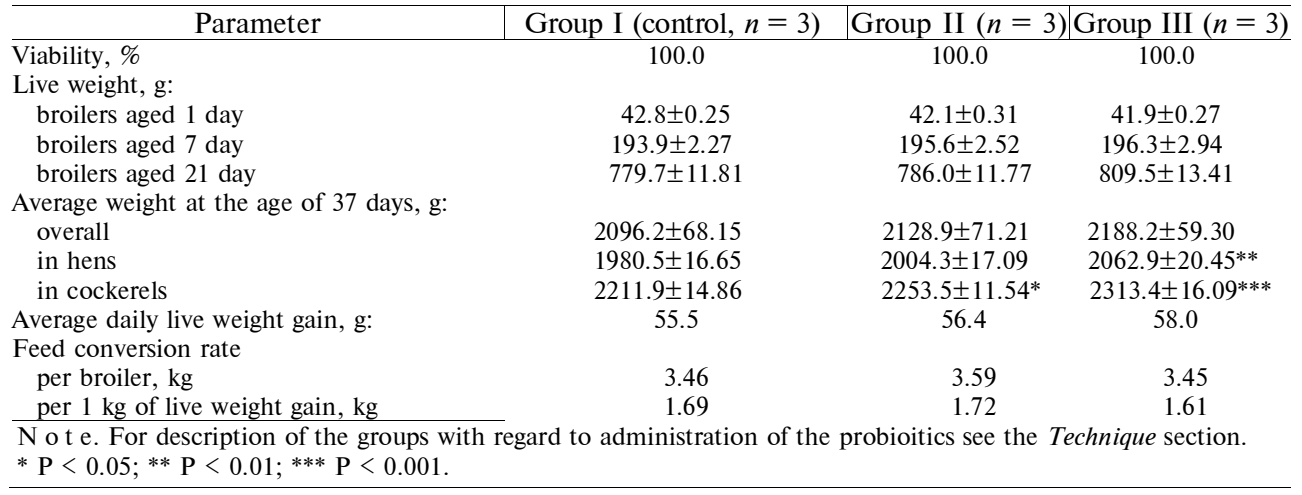

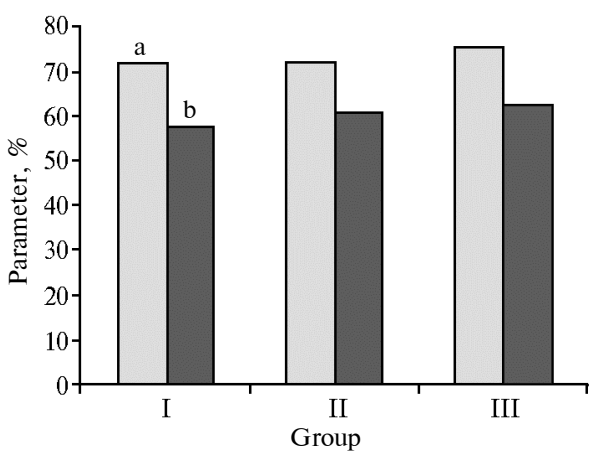

Digestibility of the feed dry matter (a) and utilization of nitrogen (b) by Cobb 500 broiler chickens, as influenced by dietary cellobacterine-T probiotic and a yeast-based probiotic (Zagorskoe EPH VNITIP vivarium, Moscow region). For description of the groups with regard to administration of the probioitics see the Technique section.

The live weight gain at the age of 7,21 , and 97 days was higher than that of the control, i.e. by $0.9,0.8$, and $1.6 \%$ for group II, and by 1.2, 3.8, and $4.4 \%$ for group III. So, the chickens consuming compound feed supplemented with cellobacterine- $\mathrm{T}$ probiotic had maximum growth rate. In group III, the live weight at the age of 37 days was above the control values by $4.2 \%(\mathrm{P} \leq 0.01)$ for female chickens, and by $4.6 \%(\mathrm{P} \leq 0.001)$ for male chickens.

When using the yeast probiotic, the feed consumption rate increased by $3.8 \%$, as compared to the control. Feed conversion rate per $1 \mathrm{~kg}$ of live weight gain in group II was higher than that in the control and group III by $1.8 \%$ and

\section{$4.7 \%$, respectively.}

The results of physiological balance test were consistent with the data on broiler productivity (Fig.). The digestibility of feed dry matter in all experimental groups was higher than that in the control. The highest digestibility, with the difference of $3.7 \%$, was in group II. This group also differed from other groups in greater average daily live weight gain of $58.0 \mathrm{~g}$. A similar pattern of the feed nitrogen utilization was in group III compared to other groups, i.e. the nitrogen utilization was significantly higher by $4.7 \%$ than that in the peers from the control group.

The probiotic additives have affected vitamin accumulation in broiler liver (Table 3). In groups II and III, as compared to the control, the level of vitamin A increased by $4.7 \%$ and $8.9 \%$, of vitamin $\mathrm{E}-$ by $7.7 \%$ and $22.1 \%(\mathrm{P}<0.01)$, 
of vitamin $\mathrm{B}_{2}-$ by $7.3 \%$ and $12.4 \%$, and the amount of carotenoids was $4.8 \%$ and $9.2 \%$ higher, respectively.

3. Vitamins and carotenoids $(\mu \mathrm{g} / \mathrm{g})$ in 37-day-old Cobb 500 broiler chicken liver, as influenced by dietary cellobacterine-T probiotic and a yeastbased probiotic (Zagorskoe «EPH VNITIP vivarium, Moscow region)

\begin{tabular}{l|c|c|c}
\hline $\begin{array}{l}\text { Bioactive } \\
\text { substances }\end{array}$ & $\begin{array}{c}\text { Group I (con- } \\
\text { trol, } n=3)\end{array}$ & $\begin{array}{c}\text { Group II } \\
(n=3)\end{array}$ & $\begin{array}{c}\text { Group III } \\
(n=3)\end{array}$ \\
\hline Vitamin A & $139.85 \pm 5.35$ & $146.40 \pm 6.12$ & $152.23 \pm 4.95$ \\
Vitamin E & $5.71 \pm 0.12$ & $6.15 \pm 0.17$ & $6.97 \pm 0.09^{*}$ \\
Vitamin $\mathrm{B}_{2}$ & $10.96 \pm 0.42$ & $11.76 \pm 0.18$ & $12.32 \pm 0.32$ \\
Carotenoids & $4.37 \pm 0.18$ & $4.58 \pm 0.02$ & $4.77 \pm 0.07$ \\
\hline $\mathrm{N}$ o t e. For description of the groups with regard to administration of the \\
probioitics see the Technique section. \\
$* \mathrm{P}<0.01$.
\end{tabular}
poultry productivity directly. V.A. Torok et al. [24)] have found the correlation between caecum microorganism composition and the effectiveness of feed energy utilization. As researchers thought, the bacteria can produce various acids, first of all butyric acid, which acts as a preferable energy source and increases the intestine epithelium size [36,37], thus these bacteria can play an important role by creating a barrier for toxic agents [38]. The representatives of phylum Firmicutes [39], including Eubacterium rectale (family Eubacteriaceae), genus Roseburia (family Lachnospiraceae), Faecalibacterium prausnitzii (family Ruminococcaceae) are the main butyric acid producers $[27,28,40]$. When analyzing both probiotics, we observed an increase in proportion of Eubacteriaceae and Ruminococcaceae microorganisms in broiler caecum. This fact may indicate that the increase in productivity is related to increase in butyric acid content in the intestine.

Additionally, some authors note the dependence of poultry productivity on the intestine content of lactic acid produced by lactobacilli of genera Lactobacillus, Enterococcus, etc. It is known that lactate has more expressed antimicrobial properties with regard to pathogens, as compared to other acids (acetic, propionic, etc.) produced by intestinal microflora. As a rule, significant amounts of lactic acid do not accumulate in the intestine due to rapid absorption and assimilation by lactate-fermenting microorganisms of genera Anaerostipes, Veillonella and Megasphaera of order Negativicutes. According to our findings, administration of cellobacterine-T lead to an increase in proportion of lactateproducing bacterial of genus Lactobacillus and a decrease in the number of lactate-fermenting bacteria of order Negativicutes, which could contribute to greater accumulation of lactic acid in the broiler intestine in group III and, consequently, to more expressed antimicrobial effect on pathogens as compared to group II. Administration of live yeast resulted in an increase in the proportion of lactatefermenting bacteria of order Negativicutes in the intestine. It could lead to better assimilation of lactic acid and, consequently, to a decrease in antimicrobial properties, as compared to group III [41, 42].

Thus, cellobacterine-T shows high probiotic activity and has a positive effect on the composition of the caecum bacterial community in broiler chickens. As a result, the number of normal flora (representatives of genera Bacillus and Lactobacillus) increases significantly, whereas the number of microorganisms traditionally related to intestine dysbiosis in humans and animals (families Enterobacteriaceae and Campylobacteriaceae) decreases. Yeast-based probiotic had a positive effect on the content of cellulosolytic microorganisms of class Clostridia; however, its effect on pathogenic microorganisms was less significant, e.g. lead to a significant increase in proportion of campylobacteria, pasteurella, and mycoplasmas. 
Both probiotics positively influenced on poultry productivity, feed digestibility, utilization of nutrients and the level of vitamins in liver. The maximum live weight gain, accelerated growth and higher digestibility of the feed nutrients, as well as accumulation of vitamins $\mathrm{A}, \mathrm{E}, \mathrm{B}_{2}$ and carotenoids in the liver were characteristic of the chickens fed with cellobacterine-T.

\section{REFEREN CES}

1. Czerwinski J., Hojberg O., Smulikowska S., Engberg R.M., Mieczkow$\mathrm{s} \mathrm{k}$ a A. Influence of dietary peas and organic acids and probiotic supplementation on performance and caecal microbial ecology of broiler chickens. Brit. Poultry Sci., 2010, 51(2): 258-569 (doi: 10.1080/00071661003777003).

2. M a lik N.I., P a n i n A.N. Veterinariya, 2001, 1: 27 (in Russ.).

3. S t a n le y D., H u g hes R.J., M o or e R.J. Microbiota of the chicken gastrointestinal tract: influence on health, productivity and disease. Appl. Microbiol. Biotechnol., 2014, 98: 4301-4309 (doi: 10.1007/s00253-014-5646-2).

4. Rodriguez-Lecompte J.C., Yitbarek A., Brady J., Sharif S., Cavanagh M.D., Crow G., Guenter W., Hous e J.D., Camelo-Jai mes G. The effect of microbialnutrient interaction on the immune system of young chicks after early probiotic and organic acid administration. J. Anim. Sci., 2012, 90(7): 2246-2254 (doi: 10.2527/jas.2011-4184).

5. Stanley D., Hughes R.J., M o ore R.J. Microbiota of the chicken gastrointestinal tract: influence on health, productivity and disease. Appl. Microbiol. Biotechnol., 2014, 98: 4301-4310 (doi: 10.1007/s00253-014-5646-2).

6. Rehman H., Vahjen W., Awad W., Zentek J. Indigenous bacteria and bacterial metabolic products in the gastrointestinal tract of broiler chickens. Arch. Anim. Nutr., 2007, 61: 319-335 (doi: 10.1080/17450390701556817).

7. Urdaci M.C., B ress ollie r P., Pinchuk I. Bacillus clausii probiotic strains: antimicrobial and immunomodulatory activities. J. Clin. Gastroenterol., 2004, 38: 86-90.

8. M a z z a P. The use of Bacillus subtilis as an antidiarrhoeal microorganism. Boll. Chim. Farm., 1994, 133: 3-18.

9. Hong H.A., Huang J.M., Khaneja R., Hi e p L.V., Urdaci M.C., Cutting S.M. The safety of Bacillus subtilis and Bacillus indicus as food probiotics. J. Appl. Microbiol., 2008, 105: 510-520 (doi: 10.1111/j.1365-2672.2008.03773.x).

10. Mountzouris K.C., Dalaka E., Palamidi I., Paraskeuas V., Demey V., Theodoropoulos G., Fegeros K. Evaluation of yeast dietary supplementation in broilers challenged or not with Salmonella on growth performance, cecal microbiota composition and Salmonella in ceca, cloacae and carcass skin. Poultry Sci., 2015, 94(10): 2445-2455 (doi: $10.3382 / \mathrm{ps} / \mathrm{pev} 243$ ).

11. M'S a d e q S.A., Wu S.B., Choct M., Forde r R., S w i c k R.A. Use of yeast cell wall extract as a tool to reduce the impact of necrotic enteritis in broilers. Poultry Sci., 2015, 94(5): 898-905 (doi: 10.3382/ps/pev035).

12. De Vries T.J., Chevaux E. Modification of the feeding behavior of dairy cows through live yeast supplementation. J. Dairy Sci., 2014, 97(10): 6499-6510 (doi: 10.3168/jds.2014-8226).

13. Zhang Z., C a o L., Zhou Y., Wang S., Z hou L. Analysis of the duodenal microbiotas of weaned piglet fed with epidermal growth factor-expressed Saccharomyces cerevisiae. BMC Microbiol., 2016, 28: 161-166 (doi: 10.1186/s12866-016-0783-7).

14. Pizzolit to R.P., Armando M.R., Combina M., Cavagli e ri L.R., Dalce ro A.M., S a lva no M.A. Evaluation of Saccharomyces cerevisiae strains as probiotic agent with aflatoxin $\mathrm{B}_{1}$ adsorption ability for use in poultry feedstuffs. J. Environ. Sci. Health. B, 2012, 47(10): 933-941 (doi: 10.1080/03601234.2012.706558).

15. Slizewska K., Pi ot rowsk a M. Reduction of ochratoxin A in chicken feed using probiotic. Ann. Agric. Environ. Med., 2014, 21(4): 676-680 (doi: 10.5604/12321966).

16. Amit-Romach E., Uni Z., Re ife n R. Multistep mechanism of probiotic bacterium, the effect on innate immune system. Mol. Nutr. Food. Res., 2010, 54: 277-284 (doi: 10.1002/mnfr.200800591).

17. Pagnini C., S a e d R., Bamias G., Arseneau K.O., Pizarro T.T., Cominelli F., Amit-Romach E., Uni Z., Reifen R. Probiotics promote gut health through stimulation of epithelial innate immunity. PNAS USA, 2010, 107: 454-459 (doi: 10.1073/pnas.0910307107).

18. Rajput I.R., H us s a n A., Li Y.L., Zhang X., Xu X., Long M.Y., You D.Y., Li W.F. Saccharomyces boulardii and Bacillus subtilis B10 modulate TLRs mediated signaling to induce immunity by chicken BMDCs. J. Cell. Biochem., 2014, 115(1): 189-198 (doi: $10.1002 /$ jcb.24650). 
19. Alizadeh M., Rogiewicz A., McMillan E., Rodriguez-Lecompte J.C., Patterson R., Slominski B.A. Effect of yeast-derived products and distillers dried grains with solubles (DDGS) on growth performance and local innate immune response of broiler chickens challenged with Clostridium perfringens. Avian Pathol., 2016, 45(3): 334-345 (doi: 10.1080/03079457.2016.ne).

20. A 1 izadeh M., Rodriguez-Lecompte J.C., Yitbarek A., Sharif S., Crow G., Slominski B.A. Effect of yeast-derived products on systemic innate immune response of broiler chickens following a lipopolysaccharide challenge. Poultry Sci., 2016, 95(10): 2266-2273 (doi: 10.3382/ps/pew154).

21. Ta rakanov B.V. Metody issledovaniya mikroflory pishchevaritel'nogo trakta sel'skokhozyaistvennykh zhivotnykh $i$ ptitsy [Study of microflora in alimentary canal of farm animals methods]. Moscow, 2006 (in Russ.).

22. Ti m o s h o M.A. Mikroflora pishchevaritel'nogo trakta sel'skokhozyaistvennykh zhivotnykh [Microflora of alimentary canal in farm animals]. Kishinev, 1990 (in Russ.).

23. Pa rk S.H., Le e S.I., Ricke S.C. Microbial populations in naked neck chicken ceca raised on pasture flock fed with commercial yeast cell wall prebiotics via an Illumina MiSeq Platform. PLoS ONE, 11(3): e0151944 (doi: 10.1371/journal.pone.0151944).

24. To rok V.A., H ugh es R.J., M k k e ls e n L.L. Identification and characterization of potential performance-related gut microbiota in broiler chickens across various feeding trials. Appl. Environ. Microbiol., 2011, 77(17): 5868-5878 (doi: 10.1128/AEM.00165-11).

25. Witzig M., Camarinha-Silva A., Green-Engert R., Hoelzle K., Zelle r E., S e ifert J., Hoelzle L.E., Rodehut s cord M. Correction: spatial variation of the gut microbiota in broiler chickens as affected by dietary available phosphorus and assessed by T-RFLP analysis and 454 pyrosequencing. PLOS ONE, 2015, 10(12): e0145588 (doi: 10.1371/journal.pone.0145588).

26. de Boer P., Rahaoui H., Leer R.J., Montijn R.C., van der Vossen J.M. Real-time PCR detection of Campylobacter spp.: a comparison to classic culturing and enrichment. Food Microbiol., 2015, 51: 96-100 (doi: 10.1016/j.fm.2015.05.006).

27. Hold G.L., Schwiertz A., A minov R.I., B laut M., Flint H.J. Oligonucleotide probes that detect quantitatively significant groups of butyrate-producing bacteria in human feces. Appl. Environ. Microbiol., 2003, 69: 4320-4324.

28. B j e r r u L L., Engberg R.M., Leser T.D., J ensen B.B., Finster K., P e d e r s e $n$ K. Microbial community composition of the ileum and cecum of broiler chickens as revealed by molecular and cellular-based techniques. Poultry Sci., 2006, 85: 1151-1164.

29. Metodika provedeniya nauchnykh i proizvodstvennykh issledovanii po kormleniyu sel'skokhozyaistvennoi ptitsy. Molekulyarno-geneticheskie metody opredeleniya mikroflory kishechnika /Pod redaktsiei V.I. Fisinina [Poultry feeding: research and practical study. Molecular methods for the analysis of gut microflora. V.I. Fisinin (ed.)]. Sergiev Posad, 2013 (in Russ.).

30. Instruktsiya po sanitarno-mikrobiologicheskomu kontrolyu tushek, myasa ptitsy, ptitseproduktov, yaits $i$ yaitseproduktov na ptitsevodcheskikh i pererabatyvayushchikh predpriyatiyakh [Instruction for the sanitary-microbiological control of poultry carcasses, meat, eggs and egg products in the poultry production and processing enterprises]. Moscow, 1990 (in Russ.).

31. Maniat is T., Frit s ch E. F., S a mbrook J. Molecular cloning: a laboratory manual. Cold Spring Harbor, NY, 1982.

32. Gong J., Forster R.J., Yu H., Chambers J.R., Sabour P.M., Whe at c roft R., $\mathrm{C}$ he n S. Diversity and phylogenetic analysis of bacteria in the mucosa of chicken ceca and comparison with bacteria in the cecal lumen. FEMS Microbiol. Lett., 2002, 208: 1-7 (doi: 10.1016/S0378-1097(01)00521-3).

33. A m it - R o m a ch E., S k la n D., U n i Z. Microflora ecology of the chicken intestine using 16S ribosomal DNA primers. Poultry Sci., 2004, 83: 1093-1098 (doi: 10.1093/ps/83.7.1093).

34. Rinttila T., Apajalahti J. Intestinal microbiota and metabolites - Implications for broiler chicken health and performance. J. Appl. Poultry Res., 2013, 22(3): 647-658 (doi: 10.3382/japr.2013-00742).

35. Sanchez B., Arias S., Chaignepain S., Denayrolles M., S chmitter J.M., B ressolli e r P., U rd a c i M.C. Identification of surface proteins involved in the adhesion of a probiotic Bacillus cereus strain to mucin and fibronectin B. Microbiology, 2009, 155: 17081716 (doi: 10.1099/mic.0.025288-0).

36. Le Blay G., Blottiere H.M., Ferrier L., Le Foli E.C., Bonnet J.P., Ga$1 \mathrm{miche}$ C., Che rbut C. Shortchain fatty acids induce cytoskeletal and extracellular protein modifications associated with modulation of proliferation on primary culture of rat intestinal smooth muscle cells. Dig. Dis. Sci., 2000, 45: 1623-1630.

37. Yasuoka T., Tsujikawa Y. Fuji y a ma, B a mba T. Effects of the soluble fibre pectin on intestinal cell proliferation, fecal short chain fatty acid production and microbial population. Digestion, 2003, 67: 42-49.

38. Niba A.T., B e a l J.D., Kudi A.C., B rooks P.H. Bacterial fermentation in the gastroin- 
testinal tract of non-ruminants: Influence of fermented feeds and fermentable carbohydrates. Trop. Anim. Health Prod., 2009, 41: 1393-1407 (doi: 10.1007/s11250-009-9327-6).

39. Pryde S.E., Duncan S.H., Hold G.L., S te wart C.S., Flint H.J. The microbiology of butyrate formation in the human colon. FEMS Microbiol. Lett., 2002, 217: 133-139.

40. Lou is P., Young P., Holtrop G., Flint H.J. Diversity of human colonic butyrateproducing bacteria revealed by analysis of the butyryl-CoA:acetate CoA-transferase gene. Environ. Microbiol., 2010, 12: 304-314 (doi: 10.1111/j.1462-2920.2009.02066.x).

41. B elenguer A., Duncan S.H., Holtrop G., Anderson S.E., Lobley G.E., Fli n t H.J. Impact of $\mathrm{pH}$ on lactate formation and utilization by human fecal microbial communities. Appl. Environ. Microbiol., 2007, 73: 6526-6533.

42. H a rms e n H.J.M., R a a ng s G.C., H e T., D e ge ne r J.E., W e 11 i ng G.W. Extensive set of $16 \mathrm{~S}$ rRNAbased probes for detection of bacteria in human feces. Appl. Environ. Microbiol., 2002, 68: 2982-2990.

43. Swiqtkiewicz S., Arczewska-Wlosek, Jozetiak D. Immunomodulatory efficacy of yeast cell products in poultry: a current review. World's Poultry Science Journal, 2014, 70(1): 57-68.

44. B i rg i t K. Hefen in der Nutztierfutterung. Feed Mag., 2015, 98(1-2): 17-21.

45. Fanelli A., Agazzi A., Alborali G.L., Pilotto A., Pilot to A., Bontem po V., De 11' O rto V., D e mey V., Caputo J.M., S avoini G. Prevalence reduction of pathogens in poultry fed with Saccharomyces cerevisiae. Biotechnol. Agron. Soc. Environ., 2015, 19(1): 3-10. 